\title{
Environment related variations in the semen characteristics of bulls used for Artificial Insemination (AI) programme in Bangladesh
}

\author{
Md. Jalal Uddin Sarder \\ Department of Animal Husbandry and Veterinary Science, Faculty of Agriculture, University of Rajshahi, Rajshahi-6205 \\ Bangladesh.
}

\begin{abstract}
The present study assessed the semen characteristics of bulls used for Artificial Insemination (AI) programme in Bangladesh with regard to season, ambient temperature and relative humidity. A total of 3720 semen samples from 71 bulls were collected from Central Cattle Breeding Station and Dairy Farm (CCBSDF), Savar, Dhaka, Rajshahi Dairy and Cattle Improvement Farm (RDCIF), Rajabarihat, Rajshahi and District Artificial Insemination Centre (DAIC), Rajshahi during 1995 - 2002. Semen was collected by artificial vaginal method once a week. Different seasons viz. spring, summer, autumn and winter had significant effect $(\mathrm{P}<0.05)$ on colour, density, mass activity, sperm concentration, sperm motility, total sperm cells/ejaculate, total number of motile sperm cells/ejaculate, number of semen doses per collection and postfreezing motility of sperm. The maximum values of these semen characteristics were found in summer. Ambient temperature groups of $<21^{\circ} \mathrm{C}, 21-25^{\circ} \mathrm{C}, 25-29^{\circ} \mathrm{C}$ and $>29^{\circ} \mathrm{C}$ had significant $(\mathrm{P}<0.05)$ effect on all the semen characteristics except for volume of semen. The highest volume of semen was found at $>29^{\circ} \mathrm{C}$ and the lowest at $25-29^{\circ} \mathrm{C}$. The total number of sperm cells/ejaculate, total number of motile sperm cells/ejaculate and number of semen doses per collection were found in $>29{ }^{\circ} \mathrm{C}$ temperature groups. Relative humidity groups of $<65 \%, 65-75 \%, 75-85 \%$ and $>85 \%$ had significant effect on all the semen characteristics excluding for volume of semen and number of semen doses per collection. The largest volume of semen, colour, mass activity, total sperm cells/ejaculate, total motile sperm cells/ejaculate and number of semen doses/collection were found in $>85 \%$ relative humidity and the smallest in $65 \%-75 \%$ relative humidity. Finally, this study recommended that, summer season, ambient temperature groups of $>29^{\circ} \mathrm{C}$ and Relative humidity groups of $>85 \%$ are suitable for excellent semen characteristics.
\end{abstract}

Key words: AI bulls, semen characteristics, season, temperature, relative humidity.

\section{Introduction}

Artificial insemination (AI) of cattle in Bangladesh is expanding day by day. Therefore, for improving the production potential and genetic merit of our nondescript indigenous cows, superior germ plasms have been introduced all over Bangladesh (Sarder et al., 2001a). The success of the programme mainly depends on the successful selection of properly fertile bulls. It is expected that the superior sire can only produce best quality semen. There are many factors that may affect the effectiveness of AI in field condition. The semen characteristics are the major factors that influence conception in cattle and therefore, a determinant of efficiency of reproduction. Among the factors, quality of semen is an important consideration. The bulls used for AI at three centres/stations are mostly cross-bred (Local $\times$ Holstein Friesian, Local $\times$ Holstein Friesian $\times$ Holstein Friesian, Sahiwal $\times$ Holstein Friesian) and pure Sahiwal, Holstein Friesian and Local. The adaptability of such exotic and cross-bred bulls in hot and humid climate as prevailing in Dhaka and Rajshahi are not known. So, a thorough knowledge of environment related variations in semen characteristics of these breeds is very important. Some breeds like Holstein
Friesian and Sahiwal are found suitable for climatic condition of Bangladesh (Sarder el al., 2001b) In general, bulls having $50 \%$ exotic blood are used for AI on indigenous cows. This is because half-bred bulls are found much suitable and treated as the best types for the most tropical region for improving indigenous animals (Nagarcenkar, 1982). Breed and season have been shown to have effects on semen production and its quality (Vincent, 1972; Meyerhoeffer et al., 1976, Parkinson, 1987, Sekoni \& Gustafsson, 1987). Tomar et al. (1966) reported that there was no seasonal trend in any semen characteristics of Hariana bulls. Seasonal variations in semen production have been observed (Ibrahim et al., 1983; Schwab et al., 1987; Graffer et al., 1988), but specific causes are not understood. As the seasons of our country varies markedly, special attention should be given to the fertility of cross-bred bulls all the year round. Information are not available on the semen characteristics such as volume, colour, density, mass activity, sperm concentration, motility, total number of sperm cells/ejaculates, total number of motile sperm cells /ejaculate, total number of semen doses/ejaculate and post-freezing motility of spermatozoa as influenced by various seasons, ambient 
temperature and relative humidity of District AI Centre, Rajshahi, CCBSDF, Savar, Dhaka and RDCIF, Rajabarihat, Rajshahi. A better knowledge of the influence of seasons of the year, ambient temperature and relative humidity during semen collection on semen characteristics of the three AI centres / stations will help the AI industry to adapt a standard management of bulls to improve semen output. The present study was therefore designed evaluate the effect of seasons, ambient temperature and relative humidity on semen characteristics of the crossbred and pure bull need for AI in the centres/stations under study.

\section{Materials and Methods}

Collection and Semen Samples: The study was conducted in three AI centres/stations, and Department of Genetics and Breeding, Rajshahi University, during the period from 1995 - 2002. For this purpose, a total of 3720 semen samples from 71 bulls were collected from Central Cattle Breeding Station and Dairy Farm (CCBSDF), Savar, Dhaka, Rajshahi Dairy and Cattle Improvement Farm (RDCIF), Rajabarihat, and District Artificial Insemination Centre (DAIC), Rajshahi. Of 3720 ejaculates, 626 from 100\% Friesian, 620 from $100 \%$ Sahiwal, 784 from $75 \% \mathrm{~F} \times 25 \% \mathrm{~L}, 572$ from $50 \%$ SL $\times 50 \%$ F, 769 from $50 \% \mathrm{~F} \times 50 \% \mathrm{~L}$ and 349 from $100 \%$ L were obtained. Semen was collected by artificial vaginal method from every bull once in a week. The semen was brought to the laboratory immediately after collection and was placed in water bath at $37^{\circ} \mathrm{C}$ for evaluation. The characteristics of semen were recorded as follows: volume of ejaculate (ml), colour (scale:1-4), density (scale:1-5), mass activity (scale:1-4), sperm concentration (million/ml), sperm motility (\%), total number of sperm cells/ejaculate (million), total number of motile sperm cells/ejaculate (million), total number of semen doses/ejaculate and post-freezing sperm motility (\%).

Feeding and management of bulls: Feeding and management systems in all three AI centres were more or less uniform throughout the year. In general, the animals were fed with concentrates and paddy straw supplementation with green grasses. Stall-feeding was practiced regularly and concentrated feeds were given two times a day. Concentrate feeds included chickpea, wheat bran, seasamum oil cake, rice polish, pulse bran and salt. The green grasses like Napier, Para, maize and oats and in the form of silage were also supplied on the basis of year round availability. The bulls were also fed a balanced ration of $50 \%$ mixed concentrate and $50 \%$ hay with supplementation of vitamins and minerals. All the bulls were kept under identical conditions of management, feeding (seasonal fodder) and watering. The bulls were housed individually in pens with sufficient cross ventilation and protection against summer heat and in an open space for sunbathing in winter.

Environmental factors: These included season, ambient temperature and relative humidity. The whole year was divided into four (4) seasons: 1) Spring- from February to April; 2) Summer- from May to July; 3) Autumn- from August to October and 4) Winter- from November to January. The ambient temperature and relative humidity were collected from the Bangladesh Meteorological Department, Regional Station, Rajshahi, situated at a distance of 5 kilometers away from DAIC, Rajshahai and 20 kilometres away from Deep frozen semen production Laboratory, RDCIF, Rajabarihat. Data were also recorded from the Bangladesh Meteorological Office, Agargoan, situated at distance of 25 kilometres away from CCBSDF, Savar, Dhaka. Ambient temperatures were classified into four groups: $<21^{\circ} \mathrm{C}, 21^{\circ}$ to $<25^{\circ} \mathrm{C}, 25^{\circ}$ to $<29^{\circ} \mathrm{C}$ and $>29^{\circ} \mathrm{C}$. Relative humidities also were classified into four groups: $<65 \%, 65 \%$ to $<75 \%, 75 \%$ to $<85 \%$ and $>85 \%$. Climatological information for these locations during the experimental season of the year is summarized in Table 1.

Table 1. Meteorological data recorded during the study period from 1995 to 2002.

\begin{tabular}{|c|c|c|c|c|c|c|}
\hline \multirow{2}{*}{$\begin{array}{l}\text { Name of AI } \\
\text { centre/station }\end{array}$} & \multirow[t]{2}{*}{ Seasons } & \multirow{2}{*}{$\begin{array}{c}\text { Number of } \\
\text { observations }\end{array}$} & \multicolumn{2}{|c|}{ Ambient temperatures $\left({ }^{\circ} \mathrm{C}\right)$} & \multicolumn{2}{|c|}{ Relative humidities (\%) } \\
\hline & & & Mean \pm SD & Range & Mean \pm SD & Range \\
\hline \multirow{5}{*}{ 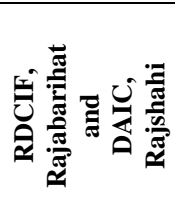 } & Spring & 329 & $24.79 \pm 4.61^{\mathrm{c}}$ & $16.40-33.0$ & $64.61 \pm 12.86^{c}$ & $35.0-93.0$ \\
\hline & Summer & 319 & $29.54 \pm 1.76^{\mathrm{a}}$ & $19.0-34.0$ & $80.79 \pm 7.94^{b}$ & $54.0-96.0$ \\
\hline & Autumn & 304 & $28.75 \pm 1.48^{b}$ & 24.75-34.0 & $85.94 \pm 4.87^{\mathrm{a}}$ & $70.0-96.4$ \\
\hline & Winter & 294 & $20.87 \pm 3.37^{d}$ & $13.40-28.80$ & $79.63 \pm 6.32^{b}$ & $61.0-96.5$ \\
\hline & Total & 1246 & $25.92 \pm 4.65$ & $13.4-34.0$ & $77.50 \pm 11.83$ & $35.0-96.5$ \\
\hline \multirow{3}{*}{  } & Spring & 678 & $25.31 \pm 3.40^{b}$ & $18.3-32.8$ & $65.84 \pm 7.27^{\mathrm{d}}$ & $47.0-93.0$ \\
\hline & Summer & 645 & $28.71 \pm 0.95^{a}$ & $20.70-32.0$ & $81.85 \pm 4.89^{b}$ & $56.6-96.6$ \\
\hline & Autumn & 581 & $28.53 \pm 1.04^{\mathrm{a}}$ & $20.81-31.50$ & $84.54 \pm 3.27^{\mathrm{a}}$ & $71.0-96.5$ \\
\hline
\end{tabular}




\begin{tabular}{|c|c|c|c|c|c|c|}
\hline & Winter & 570 & $21.68 \pm 2.83^{\mathrm{c}}$ & $13.40-29.15$ & $73.54 \pm 6.44^{\mathrm{c}}$ & $61.0-93.0$ \\
\cline { 2 - 7 } & Total & 2474 & $26.11 \pm 3.65$ & $13.4-34.0$ & $76.18 \pm 9.41$ & $47.0-96.5$ \\
\hline
\end{tabular}

CCBSDF=Central Cattle Breeding Station and Dairy Farm; DAIC= Rajshahi and District Artificial Insemination Centre; RDCIF=Rajshahi Dairy and Cattle Improvement Farm; The values are Mean \pm SD, a,b,c,d Mean \pm SD with different superscript letters in the same row differs significantly with each others.

Semen evaluation: Immediately after collecting semen was placed in a beaker containing lukewarm water and was examined for semen characteristics summarized in Table 2.

Table 2. Number of semen collections per season.

\begin{tabular}{|l|c|c|c|c|c|}
\hline \multicolumn{1}{|c|}{ AI stations } & \multicolumn{3}{c|}{ Seasons } & Total number of collections \\
\cline { 2 - 5 } & Spring & Summer & Autumn & Winter & \\
DAIC, Rajshahi & 211 & 210 & 234 & 200 & 855 \\
RDCIF, Rajabarihat, Rajshahi & 118 & 109 & 70 & 94 & 391 \\
CCBSDF, Savar, Dhaka. & 678 & 645 & 581 & 570 & 2474 \\
Total & 1007 & 964 & 885 & 864 & 3720 \\
\hline
\end{tabular}

AI= Artificial Insemination; DAIC=District Artificial Insemination centre; RDCIF=Rajshahi. Rajshahi Dairy and Cattle Improvement Farm; CCBSDF=Central Cattle Breeding Station and Dairy Farm

\section{Semen characteristics:}

1) Volume: Volume of the ejaculate was measured directly from graduated collecting tube and recorded in $\mathrm{ml}$.

2) Colour: The colour of semen was determined by eye estimation and recorded as follows. A numerical weight of 1 was assigned to opalescent /watery, 2 to milky white, 3 to yellowish white and 4 to creamy white.

3) Density: The density of semen was scored as follows: $1=$ watery to cloudy; $2=$ milky; $3=$ thin creamy; $4=$ creamy and $5=$ creamy grainy. This was also determined by eye estimation.

4) Mass activity/ wave motion: The mass activity was evaluated in a drop of fresh undiluted semen placed on a pre-warmed slide without cover-slip at low magnification $(100 \times)$. The mass activity was scored into 1- 4 scales: 1= weak motion without forming any wave; $2=$ small, slow moving wave; $3=$ vigorous movement with moderate rapid waves and eddies and $4=$ dense, very rapidly moving waves and eddies.

5) Sperm concentration: The concentration of spermatozoa (million/ml) in fresh semen was determined by using an improved Neubaur Haemocytometer (Salisbury et al., 1978) or Kara's scale at DAIC, Rajshahi.

The sperm concentration/ml was directly recorded by using a Photometer at Central AI laboratory, CCBSDF, Savar, Dhaka and Deep frozen semen production laboratory, RDCIF, Rajabarihat, Rajshahi.

6) Sperm motility / initial sperm motility: The motility of sperm was evaluated in small drop of diluted semen placed on a clean, pre-warmed slide, covered with a cover slip and examined at a magnification of $400 \times$ under light microscope at
DAIC, Rajshahi and Video microscope was used at RDCIF, Rajabarihat, Rajshahi and CCBSDF, Savar, Dhaka. Sperm motility was scored on the basis of the percentage of spermatozoa with normal forward progressive movement while those showing circling movements or oscillating at one place were regarded as immotile (Ahmad, 1994). Two examiners separately followed blind techniques for the evaluation. The average scores of sperm motility given by the two examiners were recorded.

7) Total number of spermatozoa/ejaculate: Total number of sperm cell per ejaculation was calculated by multiplying the spermatozoon concentration per ml by volume (Bane, 1952).

8) Total number of motile sperm cells/ejaculate: From the total number of sperm cells per ejaculates and motility, the number of motile sperm cells/ejaculate was calculated.

9) Total number of semen doses per ejaculate: From the volume, motility and sperm concentration, total number of semen doses/ejaculate was also calculated. The total number of insemination doses per ejaculate was calculated using the following formula for chilled semen at District AI Centre, Rajshahi.

Total no. of insemination dose/ejaculate = $\frac{\text { Volume } \times \text { Sperm conc. } \times \% \text { Motility }}{20 \times 100}$

The total number of deep frozen semen insemination dose was calculated using the following formula at Frozen semen production AI Lab.

Total dose for $\quad$ frozen
$=\left\{\left(\frac{\text { Volume } \times \text { sperm conc. }}{240} \times 2+\frac{\text { volume }}{\text { volume }}\right) \times 4\right\}$ 
10) Post-freezing motility: The frozen semen was thawed in a water-bath at $37-39^{\circ} \mathrm{C}$ for 10 to 12 seconds. The sperm motility was always evaluated at $+37^{\circ} \mathrm{C}$ using phase contrast optics (400x) by two investigators. The motility scores given by the investigators were averaged.

\section{Statistical analysis:}

Data were analyzed applying GLM (General Linear Model) for factorial experiments using SPSS computer software package (Version 10.1). DMRT was done to make specific treatment comparisons for values that were found significant by ANOVA according to procedure outlined by Steel \& Torrie (1980). The following model was used for different semen parameters:

$\boldsymbol{Y}_{i j k}=\mu+S_{i}+\boldsymbol{T}_{j}+\boldsymbol{H}_{k}+\boldsymbol{e}_{i j k}$ where,

$\boldsymbol{Y}_{i j k}$ - observed semen characteristics; $\mu$ overall mean; $\boldsymbol{S}_{\boldsymbol{i}}$ fixed effect of the ith season of collection ( $\mathrm{i}=1$

4); $\boldsymbol{T}_{\boldsymbol{j}}$ - fixed effect of the jth air / ambient temperature at collection ( $\mathrm{j}=1-4) ; \boldsymbol{H}_{\boldsymbol{k}}$ - fixed effect of the kth humidity at collection $(\mathrm{k}=1-4) ; \quad \boldsymbol{e}_{i j k}=$ is a random residual effect.

Mean effects were systematically included in the model. Random effects were assumed independently and identically distributed.

\section{Results and Discussion}

The effects of seasons, ambient temperatures and relative humidities on semen characteristics of the bulls used in AI are presented in Tables 3-5.

\section{Effect of seasons:}

Seasons have significant $(\mathrm{P}<0.05)$ effect on most of semen traits except volume. The present results conform with these of Hussain et al.(1985), Hardin et al.(1982), Tomar \& Gupta (1984), Igboeli \& Rakha (1971), Sinha \& Prasad (1966) and Sarder et al.(2000) who reported that volume of semen does not differ with season. All the values were higher in summer compared to the winter and autumn seasons. Similar observations were made by Sarder et al. (2000) and Smirnov \& Kruglyak (1980). Sarder et al. (2000) observed that volume of ejaculate for spring, summer, autumn and winter were $6.69 \pm 1.78 \mathrm{ml}, 6.91 \pm 1.41 \mathrm{ml}$, $6.27 \pm 1.97 \mathrm{ml}$ and $6.74 \pm 1.62 \mathrm{ml}$, respectively. The highest significant sperm concentration was observed in summer $(1333.2 \pm 340.4$ million $/ \mathrm{ml})$ and no significant differences was found with spring and autumn. Tomar \& Gupta (1984) reported that the initial motility and sperm concentration were both found to be significantly $(\mathrm{P}<0.05)$ higher during summer season than the cold season. The initial motility and sperm concentration was higher in summer (4.3 \pm 2.0 ,
$1193 \pm 52.2 \mathrm{million} / \mathrm{ml}$ respectively) and lower in winter season (3.8 \pm 0.2 and $822.7 \pm 39.9$ million $/ \mathrm{ml}$, respectively) supported the present study. In contrast, Hussain et al. (1985) found highest sperm concentration in winter and lowest in summer seasons while Kibria et al. (1997) found highest sperm concentration in spring and lowest in summer. In this study, the season had significant $(\mathrm{P}<0.05)$ effect on sperm motility which varied from $63.38 \pm 4.37$ to $64.34 \pm 4.84 \%$. Amir et al. (1982) reported that the bulls and seasons significantly affected semen volume, sperm concentration and sperm motility before and after freezing. However, seasons had no significant effect on sperm motility as reported by Hussain et al. (1985), Mathevon et al. (1998a), Sarder et al. (2000) and Saxena \& Tripathi (1984). Seasonal effects are caused by several factors such as ambient temperature, relative humidity, day length and food quality (Mathevon et al., 1998b). According to Godfrey et al. (1990), in the influence of season on sperm concentration depends on breed and location. Studies conducted in France reported either slight increase (Gerard and Humblot, 1993) or a small decrease (Gerard \& Humblot, 1992) in semen output during summer. Labesse et al. (1987) observed a decrease in semen volume during an exceptional dry summer, leading to greater sperm concentration. Seasonal changes could also be accompanished by a modification in diet, which might influence semen production (Siratskii, 1990).

\section{Effect of ambient temperatures:}

The data on the effect of ambient temperatures on semen characteristics are furnished in Table 4 . All the semen characteristics were affected significantly due to variations in the ambient temperatures except volume of semen. The volume of ejaculate was found highest $(7.23 \mathrm{ml})$ at $>29^{\circ} \mathrm{C}$ and lowest $(7.09 \mathrm{ml})$ at $25-29^{\circ} \mathrm{C}$. The highest average density (3.59), mass activity (2.96) and sperm concentration (1331.0 million/ml) were found at $25-29^{\circ} \mathrm{C}$. The volume, total number sperm cells/ejaculate, total number motile sperm cells/ejaculate and number of semen doses per collection were highest at $>29^{\circ} \mathrm{C}$. Semen quality depended on the environmental temperature (Alvarez et al., 1996; Bhuiyan \& Shamsuddin, 1998; Mathevon et al., 1998a). Ambient temperature normalcy in spermatogenesis and epididymal function can also influence the quality of fresh and preserved semen (Rathore, 1970; Gustafsson et al.,1972; Settergren \& McEntee, 1992). However, the bulls of the present study were reared under more or less stable 
environmental conditions and apparently there were no indication of impaired spermatogenesis or epididymal dysfunction during clinical evaluation of fresh semen.

Therefore, it is likely that the variation in the semen quality in the present study may be due to differences in the age and breed of the bulls.

Table 3. Seasonal effects on the semen characteristics of 71 bulls for AI programme in Bangladesh

\begin{tabular}{|c|c|c|c|c|c|}
\hline \multirow{2}{*}{ Semen characteristics } & \multicolumn{4}{|c|}{ Seasons } & \multirow[b]{2}{*}{ Total } \\
\hline & Spring & Summer & Autumn & Winter & \\
\hline Volume (ml) & $\begin{array}{c}7.15 \pm 1.13 \\
n=1007\end{array}$ & $\begin{array}{c}7.20 \pm 2.11 \\
n=964\end{array}$ & $\begin{array}{c}7.10 \pm 2.13 \\
n=885\end{array}$ & $\begin{array}{c}7.13 \pm 2.06 \\
n=864\end{array}$ & $\begin{array}{c}7.14 \pm 2.11 \\
n=3720\end{array}$ \\
\hline Colour(1-4)* & $\begin{array}{c}3.21 \pm 0.97^{a b} \\
n=1007\end{array}$ & $\begin{array}{c}3.25 \pm 0.99^{\text {ab }} \\
n=964\end{array}$ & $\begin{array}{c}3.28 \pm 0.96^{\mathrm{a}} \\
\mathrm{n}=885\end{array}$ & $\begin{array}{c}3.16 \pm 0.97^{b} \\
n=864\end{array}$ & $\begin{array}{c}3.23 \pm 0.97 \\
\mathrm{n}=3720\end{array}$ \\
\hline $\begin{array}{l}\begin{array}{l}\text { Density } \\
(1-5 \text { scale)** }\end{array} \\
\end{array}$ & $\begin{array}{c}3.57 \pm 0.76^{\mathrm{a}} \\
\mathrm{n}=1007\end{array}$ & $\begin{array}{c}3.59 \pm 0.82^{\mathrm{a}} \\
\mathrm{n}=964\end{array}$ & $\begin{array}{c}3.59 \pm 0.78^{\mathrm{a}} \\
\mathrm{n}=885\end{array}$ & $\begin{array}{c}3.49 \pm 0.77^{b} \\
n=864\end{array}$ & $\begin{array}{c}3.56 \pm 0.78 \\
\mathrm{n}=3720\end{array}$ \\
\hline Mass activity (1-4 scale)*** & $\begin{array}{c}2.89 \pm 0.69^{\text {bc }} \\
n=1007\end{array}$ & $\begin{array}{c}2.98 \pm 1.08^{\mathrm{a}} \\
\mathrm{n}=964\end{array}$ & $\begin{array}{c}2.93 \pm 0.71^{\mathrm{ab}} \\
\mathrm{n}=885\end{array}$ & $\begin{array}{c}2.83 \pm 0.67^{\mathrm{c}} \\
\mathrm{n}=864\end{array}$ & $\begin{array}{c}2.91 \pm 0.81 \\
\mathrm{n}=3720\end{array}$ \\
\hline $\begin{array}{l}\text { Sperm concentration }\left(\times 10^{6}\right) \\
/ \mathrm{ml}\end{array}$ & $\begin{array}{c}1313.5 \pm 300.5^{\mathrm{a}} \\
\mathrm{n}=1007\end{array}$ & $\begin{array}{c}1333.2 \pm 340.4^{\mathrm{a}} \\
\mathrm{n}=964\end{array}$ & $\begin{array}{c}1329.4 \pm 130.4^{\mathrm{a}} \\
\mathrm{n}=885\end{array}$ & $\begin{array}{c}1279.3 \pm 293.0^{b} \\
\mathrm{n}=864\end{array}$ & $\begin{array}{c}1314.5 \pm 312.6 \\
\mathrm{n}=3720\end{array}$ \\
\hline Sperm motility (\%) & $\begin{array}{c}64.04 \pm \\
4.44^{\mathrm{a}} \mathrm{n}=1007\end{array}$ & $\begin{array}{c}64.34 \pm 4.84^{\mathrm{a}} \\
\mathrm{n}=964\end{array}$ & $\begin{array}{c}63.97 \pm 4.72^{\mathrm{a}} \\
\mathrm{n}=885\end{array}$ & $\begin{array}{c}63.38 \pm 4.37^{b} \\
\mathrm{n}=864\end{array}$ & $\begin{array}{c}63.95 \pm 4.61 \\
n=3720\end{array}$ \\
\hline $\begin{array}{l}\text { Total sperm cells / ejaculate } \\
\left(\times 10^{6}\right)\end{array}$ & $\begin{array}{c}9451.7 \pm 3551.7^{\mathrm{ab}} \\
\mathrm{n}=1007\end{array}$ & $\begin{array}{c}9486.7 \pm 3344.5^{\mathrm{a}} \\
\mathrm{n}=964\end{array}$ & $\begin{array}{c}9414.7 \pm 3517.6^{\mathrm{ab}} \\
\mathrm{n}=885\end{array}$ & $\begin{array}{c}9123.1 \pm 3285.7^{b} \\
n=864\end{array}$ & $\begin{array}{c}9375.7 \pm 3431.5 \\
\mathrm{n}=3720\end{array}$ \\
\hline $\begin{array}{l}\text { Total motile sperm cells / } \\
\text { ejaculate }\left(\times 10^{6}\right)\end{array}$ & $\begin{array}{c}6089 \pm 2377^{\mathrm{a}} \\
\mathrm{n}=1007\end{array}$ & $\begin{array}{c}6126 \pm 2268^{\mathrm{a}} \\
\mathrm{n}=964\end{array}$ & $\begin{array}{c}6053 \pm 2371^{\mathrm{a}} \\
\mathrm{n}=885\end{array}$ & $\begin{array}{c}5801 \pm 2148^{b} \\
n=864\end{array}$ & $\begin{array}{c}6023 \pm 2299 \\
n=3720\end{array}$ \\
\hline $\begin{array}{l}\text { No. of semen doses per } \\
\text { collection }\end{array}$ & $\begin{array}{c}315.1 \pm 119.9^{\mathrm{a}} \\
\mathrm{n}=1007\end{array}$ & $\begin{array}{c}315.7 \pm \\
112.2^{\mathrm{a}} \mathrm{n}=964 \\
\end{array}$ & $\begin{array}{c}313.1 \pm 117.7^{\text {ab }} \\
\mathrm{n}=885\end{array}$ & $\begin{array}{c}303.3 \pm 110.4^{b} \\
n=864\end{array}$ & $\begin{array}{c}312.0 \pm 115.3 \\
\mathrm{n}=3720\end{array}$ \\
\hline Post-freezing motility (\%) & $\begin{array}{c}55.56 \pm 5.77^{\mathrm{a}} \\
\mathrm{n}=636\end{array}$ & $\begin{array}{c}55.58 \pm 5.54^{a} \\
n=573\end{array}$ & $\begin{array}{c}54.21 \pm 5.66^{\mathrm{b}} \\
\mathrm{n}=509\end{array}$ & $\begin{array}{c}54.85 \pm 5.42^{b} \\
n=540\end{array}$ & $\begin{array}{c}55.09 \pm 5.63 \\
\mathrm{n}=2258\end{array}$ \\
\hline
\end{tabular}

$(1-4) * ; 1=$ Opalescent, 2=Milky white, $3=$ yellowish white and 4=creamy white. (1-5)**; 1=watery, 2=milky, 3=mild creamy, $4=$ creamy and $5=$ creamy grainy. (1-4)***; $1=$ weak motion without forming any wave, $2=$ small, slow moving wave, $3=$ vigorous movement with moderate rapid waves and eddis and $5=$ dense, very rapidly moving wave and eddis. $n=$ Number of observations, The values are Mean \pm SD, a,b,c, Mean \pm SD with different superscript letters in the same raw differs significantly with each others by DMRT at $\mathrm{P}<0.05$.

Table 4. Effect of ambient temperatures on the semen characteristics of AI bulls used in Bangladesh

\begin{tabular}{|c|c|c|c|c|c|}
\hline \multirow{2}{*}{ Semen characteristics } & \multicolumn{4}{|c|}{ Temperature groups } & \multirow[b]{2}{*}{ Overall } \\
\hline & $<21^{\circ} \mathrm{C}$ & 21 to $\leq 25^{\circ} \mathrm{C}$ & 25 to $\leq 29^{\circ} \mathrm{C}$ & $>29^{\circ} \mathrm{C}$ & \\
\hline Volume (ml) & $\begin{array}{c}7.16 \pm 2.07 \\
\mathrm{n}=644\end{array}$ & $\begin{array}{c}7.13 \pm 2.13 \\
\mathrm{n}=621\end{array}$ & $\begin{array}{c}7.09 \pm 2.11 \\
\mathrm{n}=1553\end{array}$ & $\begin{array}{c}7.23 \pm 2.11 \\
\mathrm{n}=902\end{array}$ & $\begin{array}{c}7.14 \pm 2.11 \\
\mathrm{n}=3720\end{array}$ \\
\hline Colour (1-4)* & $\begin{array}{c}3.20 \pm 0.97^{\mathrm{ab}} \\
\mathrm{n}=644\end{array}$ & $\begin{array}{c}3.16 \pm 0.98^{b} \\
n=621\end{array}$ & $\begin{array}{c}3.24 \pm 0.97^{\mathrm{ab}} \\
\mathrm{n}=1553\end{array}$ & $\begin{array}{c}3.27 \pm 0.98^{\mathrm{a}} \\
\mathrm{n}=902\end{array}$ & $\begin{array}{c}3.23 \pm 0.97 \\
\mathrm{n}=3720\end{array}$ \\
\hline $\begin{array}{l}\text { Density } \\
(1-5 \text { scale)** }\end{array}$ & $\begin{array}{c}3.48 \pm 0.79^{c} \\
n=644\end{array}$ & $\begin{array}{c}3.54 \pm 0.74^{\text {ab }} \\
n=621\end{array}$ & $\begin{array}{c}3.59 \pm 0.79^{\mathrm{a}} \\
\mathrm{n}=1553\end{array}$ & $\begin{array}{c}3.58 \pm 0.80^{\mathrm{a}} \\
\mathrm{n}=902\end{array}$ & $\begin{array}{c}3.56 \pm 0.78 \\
\mathrm{n}=3720\end{array}$ \\
\hline Mass activity (1-4 scale) $)^{* * *}$ & $\begin{array}{c}2.79 \pm 0.65^{c} \\
n=644\end{array}$ & $\begin{array}{c}2.87 \pm 0.67^{b} \\
n=621\end{array}$ & $\begin{array}{c}2.96 \pm 0.94^{\mathrm{a}} \\
\mathrm{n}=1553\end{array}$ & $\begin{array}{c}2.93 \pm 0.75^{\mathrm{ab}} \\
\mathrm{n}=902\end{array}$ & $\begin{array}{c}2.91 \pm 0.81 \\
\mathrm{n}=3720\end{array}$ \\
\hline Sperm concentration $\left(\times 10^{6}\right) / \mathrm{ml}$ & $\begin{array}{c}1271.5 \pm 294.6^{b} \\
n=644\end{array}$ & $\begin{array}{c}1297.4 \pm 284.6^{b} \\
n=621\end{array}$ & $\begin{array}{c}1331.0 \pm 322.1^{\mathrm{a}} \\
\mathrm{n}=1553\end{array}$ & $\begin{array}{c}1328.5 \pm 323.5^{\mathrm{a}} \\
\mathrm{n}=902\end{array}$ & $\begin{array}{c}1314.5 \pm 312.6 \\
n=3720\end{array}$ \\
\hline Sperm motility (\%) & $\begin{array}{c}63.60 \pm 3.93^{b} \\
n=644\end{array}$ & $\begin{array}{c}63.51 \pm 4.78^{b} \\
n=621\end{array}$ & $\begin{array}{c}64.49 \pm 4.63^{\mathrm{a}} \\
\mathrm{n}=1553\end{array}$ & $\begin{array}{c}63.55 \pm 4.80^{\mathrm{b}} \\
\mathrm{n}=902\end{array}$ & $\begin{array}{c}63.95 \pm 4.61 \\
\mathrm{n}=3720\end{array}$ \\
\hline $\begin{array}{l}\text { Total sperm cells/ejaculate } \\
\left(\times 10^{6}\right)\end{array}$ & $\begin{array}{c}9162.8 \pm 3418.9^{c} \\
n=644\end{array}$ & $\begin{array}{c}9251.7 \pm 3306.7^{\text {ab }} \\
n=621\end{array}$ & $\begin{array}{c}9388.1 \pm 3409.4^{\mathrm{ab}} \\
\mathrm{n}=1553\end{array}$ & $\begin{array}{c}9591.7 \pm 3553.1^{\mathrm{a}} \\
\mathrm{n}=902\end{array}$ & $\begin{array}{c}9375.7 \pm 3431.5 \\
n=3720\end{array}$ \\
\hline $\begin{array}{l}\text { Total motile sperm } \\
\text { cells/ejaculate }\left(\times 10^{6}\right)\end{array}$ & $\begin{array}{c}5840 \pm 2220^{b} \\
n=644\end{array}$ & $\begin{array}{c}5912 \pm 2213^{a b} \\
n=621\end{array}$ & $\begin{array}{c}6081 \pm 2298^{\text {a }} \\
n=1553\end{array}$ & $\begin{array}{c}6131 \pm 2299^{\text {a }} \\
n=902\end{array}$ & $\begin{array}{c}6023 \pm 2299 \\
n=3720\end{array}$ \\
\hline $\begin{array}{l}\text { No. of semen doses per } \\
\text { collection }\end{array}$ & $\begin{array}{c}304.8 \pm \\
115.1^{\mathrm{b}} \mathrm{n}=644\end{array}$ & $\begin{array}{c}308.0 \pm 111.3^{\mathrm{ab}} \\
\mathrm{n}=621\end{array}$ & $\begin{array}{c}312.6 \pm 114.3^{\mathrm{ab}} \\
\mathrm{n}=1553\end{array}$ & $\begin{array}{c}319.0 \pm 119.6^{a} \\
n=760\end{array}$ & $\begin{array}{c}312.0 \pm 115.3 \\
\mathrm{n}=3720\end{array}$ \\
\hline Post-freezing motility (\%) & $\begin{array}{c}54.54 \pm 5.82^{b} \\
n=390\end{array}$ & $\begin{array}{c}55.41 \pm 5.56^{a} \\
n=388\end{array}$ & $\begin{array}{c}55.66 \pm 5.69^{a} \\
n=990\end{array}$ & $\begin{array}{c}54.12 \pm 5.50^{b} \\
n=490\end{array}$ & $\begin{array}{c}55.09 \pm 5.63 \\
\mathrm{n}=2258\end{array}$ \\
\hline
\end{tabular}

(1-4)*; 1=Opalescent, 2=Milky white, $3=$ yellowish white and 4=creamy white. (1-5)**; 1=watery, $2=$ milky, 3=mild creamy, $4=$ creamy and $5=$ creamy grainy. (1-4)***; $1=$ weak motion without forming any wave, $2=$ small, slow moving wave, $3=$ vigorous movement with moderate rapid waves and eddis and $5=$ dense, very rapidly moving wave and eddis. $n=$ Number of observations, The values are Mean \pm SD, a,b,c, Mean \pm SD with different superscript letters in the same row differs significantly with each others by DMRT at $\mathrm{P}<0.05$. 
Table 5. Effects of relative humidity on the semen characteristics of AI bulls used in Bangladesh

\begin{tabular}{|c|c|c|c|c|c|}
\hline \multirow{2}{*}{ Semen characteristics } & \multicolumn{4}{|c|}{ Humidity groups } & \multirow[b]{2}{*}{ Overall } \\
\hline & $<65 \%$ & 65 to $\leq 75 \%$ & 75 to $\leq 85 \%$ & $>85 \%$ & \\
\hline Volume (ml) & $\begin{array}{c}7.16 \pm 2.12 \\
n=572\end{array}$ & $\begin{array}{c}7.12 \pm 2.11 \\
n=742\end{array}$ & $\begin{array}{c}7.12 \pm 2.11 \\
n=1713\end{array}$ & $7.23 \pm 2.07 \mathrm{n}=693$ & $\begin{array}{c}7.14 \pm 2.11 \\
n=3720\end{array}$ \\
\hline Colour* & $\begin{array}{c}3.31 \pm 0.95^{\mathrm{a}} \\
\mathrm{n}=572\end{array}$ & $\begin{array}{c}3.07 \pm 0.99^{b} \\
n=742\end{array}$ & $\begin{array}{c}3.24 \pm 0.96^{\mathrm{a}} \\
\mathrm{n}=1713\end{array}$ & $\begin{array}{c}3.29 \pm 0.99^{a} \\
n=693\end{array}$ & $\begin{array}{c}3.23 \pm 0.97 \\
\mathrm{n}=3720\end{array}$ \\
\hline $\begin{array}{l}\text { Density } \\
\text { (D; 1-5 scale)** }\end{array}$ & $\begin{array}{c}3.59 \pm 0.72^{\text {a }} \\
n=572\end{array}$ & $\begin{array}{c}3.48 \pm 0.78^{b} \\
n=742\end{array}$ & $\begin{array}{c}3.59 \pm 0.80^{\text {a }} \\
\mathrm{n}=1713\end{array}$ & $\begin{array}{c}3.56 \pm 0.79^{a} \\
n=693\end{array}$ & $\begin{array}{c}3.56 \pm 0.78 \\
n=3720\end{array}$ \\
\hline Mass activity (1-5 scale)*** & $\begin{array}{c}2.90 \pm 0.66^{a b} \\
n=572\end{array}$ & $\begin{array}{c}2.83 \pm 0.69^{b} \\
n=742\end{array}$ & $\begin{array}{c}2.94 \pm 0.91^{a} \\
n=1713\end{array}$ & $\begin{array}{c}2.94 \pm 0.76^{\mathrm{a}} \\
\mathrm{n}=693\end{array}$ & $\begin{array}{c}2.91 \pm 0.81 \\
n=3720\end{array}$ \\
\hline Sperm concentration $\left(\times 10^{6}\right) / \mathrm{ml}$ & $\begin{array}{c}1319.4 \pm 286.5^{\mathrm{a}} \\
\mathrm{n}=572\end{array}$ & $\begin{array}{c}1280.1 \pm 299.1^{b} \\
n=742\end{array}$ & $\begin{array}{c}1325.8 \pm 321.2^{a} \\
n=1713\end{array}$ & $\begin{array}{c}1319.2 \pm 323.5^{\mathrm{a}} \\
\mathrm{n}=693\end{array}$ & $\begin{array}{c}1314.5 \pm 312.6 \\
n=3720\end{array}$ \\
\hline Sperm motility (\%) & $\begin{array}{c}64.87 \pm 4.27^{\text {a }} \\
n=572\end{array}$ & $\begin{array}{c}63.03 \pm 4.77^{\mathrm{c}} \\
\mathrm{n}=742\end{array}$ & $\begin{array}{c}64.24 \pm 4.55^{b} \\
n=1713\end{array}$ & $\begin{array}{c}6344 \pm 4.64^{c} \\
n=693\end{array}$ & $\begin{array}{c}63.95 \pm 4.61 \\
n=3720\end{array}$ \\
\hline $\begin{array}{l}\text { Total sperm cells/ejaculate } \\
\left(\times 10^{6}\right)\end{array}$ & $\begin{array}{c}9476.0 \pm 3459.2^{\mathrm{ab}} \\
\mathrm{n}=572\end{array}$ & $\begin{array}{c}9140.9 \pm 3403.1^{b} \\
n=742\end{array}$ & $\begin{array}{c}9388.6 \pm 3441.0^{\mathrm{ab}} \\
\mathrm{n}=1713\end{array}$ & $\begin{array}{c}9512.3 \pm 3469.1^{\text {a }} \\
n=693\end{array}$ & $\begin{array}{c}9375.7 \pm 3431.5 \\
n=3720\end{array}$ \\
\hline $\begin{array}{l}\text { Total motile sperm } \\
\text { cells/ejaculate }\left(\times 10^{6}\right)\end{array}$ & $\begin{array}{c}6166 \pm 2313^{\mathrm{a}} \\
\mathrm{n}=572\end{array}$ & $\begin{array}{c}5793 \pm 2243^{b} \\
n=742\end{array}$ & $\begin{array}{c}6059 \pm 2310^{a} \\
n=1713\end{array}$ & $\begin{array}{c}6062 \pm 2306^{\mathrm{a}} \\
\mathrm{n}=693\end{array}$ & $\begin{array}{c}6023 \pm 2299 \\
n=3720\end{array}$ \\
\hline $\begin{array}{l}\text { No. of semen doses per } \\
\text { collection }\end{array}$ & $\begin{array}{c}316.2 \pm 116.9 \\
n=572\end{array}$ & $\begin{array}{c}304.3 \pm 114.1 \\
n=742\end{array}$ & $\begin{array}{c}312.2 \pm 114.7 \\
\mathrm{n}=1713\end{array}$ & $\begin{array}{c}316.4 \pm 116.4 \\
n=693\end{array}$ & $\begin{array}{c}312.0 \pm 115.3 \\
n=3720\end{array}$ \\
\hline Post-freezing motility (\%) & $\begin{array}{c}55.86 \pm 5.57^{\mathrm{a}} \\
\mathrm{n}=359\end{array}$ & $\begin{array}{c}55.66 \pm 5.81^{\text {a }} \\
n=474\end{array}$ & $\begin{array}{c}55.22 \pm 5.42^{\mathrm{a}} \\
\mathrm{n}=1034\end{array}$ & $\begin{array}{c}53.33 \pm 5.66^{b} \\
n=391\end{array}$ & $\begin{array}{c}55.09 \pm 5.63 \\
\mathrm{n}=2258\end{array}$ \\
\hline
\end{tabular}

(1-4)*; 1=Opalescent, 2=Milky white, 3= yellowish white and 4=creamy white. (1-5)**; 1=watery, 2=milky, 3=mild creamy, $4=$ creamy and $5=$ creamy grainy. (1-4)***; $1=$ weak motion without forming any wave, $2=$ small, slow moving wave, $3=$ vigorous movement with moderate rapid waves and eddis and $5=$ dense, very rapidly moving wave and eddis. $n=$ Number of observations, The values are Mean \pm SD, a,b,c Mean \pm SD with different superscript letters in the same row differs significantly with each others by DMRT at $\mathrm{P}<0.05$.

\section{Effect of and relative humidities :}

Mean \pm SD values of the semen characteristics recorded for the relative humidity groups are shown in Table 5. The highest volume, colour, mass activity, total sperm cells/ejaculate, total motile sperm cell/ejaculate and number of semen doses per collection were observed at $>85 \%$ relative humidity groups. The relative humidity had significant effects on all the semen characteristics except the volume of ejaculate and number of semen doses/collection. The variation of the semen traits obtained in this study might be due to environmental, climatic and management factors.

The present study clearly demonstrated that the semen characteristics of the bulls used in AI programme largely depended on the seasons of the year, ambient temperatures and relative humidity values at which the semen is preserved. Summer season, temperature of $>29^{\circ} \mathrm{C}$ and relative humidity of $>85 \%$ were suitable for improved semen characteristics of the bulls under study.

\section{Acknowledgements:}

The author is grateful to Dr. O.I Joarder, Professor, Dept. Genetic Engineering and Biotechnology, University of Rajshahi for his scholastic advice, constructive suggestions, cordial help and inspiration. The author is also grateful to Professor M. Sohrab Ali, Dept. of Zoology, University of Rajshahi, Bangladesh. The author acknowledges the research material support and study leave grant by the Directorate of Livestock Services (DLS), Dhaka, Bangladesh.

\section{References}

Ahmad, N. 1994. Clinical and experimental studies of reproductive functions in the ram and male goat with special reference to the use of diagnostic ultrasound. Unpublished Ph.D Thesis. Department of Large Animal Med. \& Surgery, Royal Vet. College, University of London. London.

Alvarez, J.L., Aviles. A.T., Bravo, A.B. \& Morales, C. 1996. Spermatozoa viability and acrosomal status in Holstein and Siboney de Cuba bulls (Viabilidad de los espermatozodes yestado del acrosome en toros Holstein Siboney de Cuba). Resista de salud Ani. 18: 87-91.

Amir, D.M., Kalay, D. \& Schindler, 1982. The contribution of bulls and cows to the seasonal differences in the fertility of dairy cattle in Israel. Anim. Reprod. Sci. 5: 93-98.

Bane, A. 1954. Studies on monozygous cattle twins. $X V$. Sexual functions of bulls in relation to heredity, rearing intensity and somatic conditions. Acta Agric. Scand. 2: 95-208.

Bhuiyan, M.M.U. \& Shamsuddin, M. 1998. Bull sperm morphology in context of ambient temperature during semen collection, Bangladesh Vet. J. 32: 33-39. 
Gerard, O. \& Humblot, P. 1992. Influence of rythme de collecte, de la race et de la saison sur la production de semence de taureaux Prim 'Holstein, Normands et Charolais. I- Effets sur les arametres du sperme frais. El. Insem. 24: 9-17.

Gerard, O. \& Humblot, P. 1993. Influence of du rhythm de collecte, de la race et de la saison sur la production de semence de taueaux Prim'Holstein, Normaands et Charolais. II. Effect sur less paramtees quantitatifs de production. El Insem. 254: 13-22.

Godfrey, R.W., Lunstra, D.D., Jenkins, T.G., Berardinelli, J.G., Guthrie, M.J., Neuendorff, D.A., Long, C.R. \& Randel, R.D. 1990. Effect of season and location on semen quality and serum concentration of luteinizing hormone and testosterone in Brahman and Hereford bulls. $J$. Anim. Sci. 68: 734-749.

Graffer, T., Solbu, H. \& Filseth, O. 1988. Semen production in artificial insemination bulls in Norway. Theriogenol. 30: 1011-1021.

Gustafsson, B., Crabo, B. \& Rao, A.R. 1972. Two cases of bovine epididymal dysfunction. Cornell Vet. 62: 393-402.

Hardin, D.R., Chenoweth, P.J., Friend, T.H. \& Randel, R.D. 1982. Seasonal variation in seminal parameters and libido of Angus and Brahman bulls. Anim. Breed. Abstr. 51: 679.

Hussain, S.S., Ahmed, Ali., Mostafa, K.G. \& Bhuiyan, A.K.F.H. 1985. Effect of season on semen characteristics of crossbred bulls under field conditions. Bangladesh J. Anim. Sci. 14: 18-22.

Ibrahim, M.A.R., Rahman, H.A., Toth, B.L. \& Abedin, M. 1983. Effect on season and bacterial contamination on semen quality, freezability, and fertility of Hungarian Simmental artificial insemination bulls. Acta-Vet.-Hungaeca. 31: 81-85.

Igboeli, G. \& Rakha, 1971. Seasonal changes in ejaculate characteristics of Angoni (short horn Zebu) bulls. National council for scientific research, Chilanga, Zambia. J. Anim. Sci. 33: 651-654.

Kibria, S.S., Nahar, T.N., Mia, M.M. \& Talukder, A.I. 1997. Effect of Genetic Group, Season and Age of Bull on Semen Characteristics. Bang. J. Livestock Res. 1-5: 92-102.

Labesse, S., Humblot, P., Guerin, J.L., Gaillard, J., Gastinel, P.L., Colleau, J.J. \& Thibier, M. 1987. Analyse des donnees de controle de la fonction sexuelle chez le taurillon Normand. Relation entre niveaux de croissance et caracteristiques seminales. El. Insem. 218: 11-20.
Mathevon, M., Dekkers, J.C.M. \& Buhr, M.M. 1998a. Environmental, management, and genetic factors affecting semen production in French Montbeliard bulls. Livestock Prod. Sci. 55: 65-77.

Mathevon, M., Buhr, M.M. \& Dekkers, J.C.M. 1998b. Environmental, management, and genetic factors affecting semen production in Holstein bulls. $J$. Dairy Sci. 81: 3321-3330.

Meyerhoeffer, D.C., Weffermann, R.P., Wells, M.E. \& Turman, E.J. 1976. Effect of elevated ambient temperature on bulls. J. Anim. Sci. 43: 297

Nagarcenkar, R. 1882. Breeding for dairy Production in the tropics. In $2^{\text {nd }}$ world congress on Genetics applied to livestock production. National Dairy Research Institute, Karnal, India.

Parkinson, T.J. 1987. Seasonal variations in semen quality of bulls: Correlation's with environmental temperature. The Vet. Record 120: 479-442.

Rathore, A.K. 1970. Acrosomal abnormality in ram spermatozoa due to heat stress. Br. Vet. J. 126: 440-443.

Salisbury, G.W., Vandemark, N.L. \& Lodge, J.R. 1978. Physiology of Reproduction and Artificial Insemination of Cattle, $2^{\text {nd }}$ ed. $\mathrm{H}$ Freeman and Co. San Francisco.USA.

Sarder, M.J.U., Joarder, O.I., Ali, M.S. \& Imam, M.H. 2000. Influence of genetic group, season and age on semen characteristics of breeding bulls. Bangladesh J. genet. biotechnol. 1: 51-57.

Sarder, M.J.U., Joarder, O.I. \& Ali, M.S. 2001a. Semen production in relation to the age and season of Friesian cross and Sahiwal bulls for artificial insemination. J. bio.sci. 9: 39-46.

Sarder, M.J.U., Joarder, O.I. \& Ali, M.S. 2001b. Studies on phenotypic and genotypic variation in the semen traits of seven AI bulls. Bangladesh $J$. genet. biotechnol. 2: 35-42.

Semen production in relation to the age and season of Friesian cross and Sahiwal bulls for artificial insemination J. bio.sci. 9: 39-46.

Saxena, V.B. \& Tripathi, S.S. 1984. Variation in semen quality and preservation in Jersey bulls due to seasons. Indian J. Anim. Res. 18: 11-16.

Schwab, W., Kupferschmied, H. \& Bachmann, P. 1987. Factors affecting semen production bulls. Zuchthygiene. 22: 241-246.

Sekoni, V.O \& Gustafsson, B.K. 1987. Seasonal variation in the incidence of sperm morphological abnormalities in dairy bulls regularly used for artificial insemination. Br. Vet. J. 143: 312-317. 
Settergren, I. \& McEntee, K. 1992. Germ cell weakness as a cause of testicular hypoplasia in bulls. Acta. Vet. Scand. 33: 273-282.

Sinha, H.S. \& Prasad, R.B. 1966. Seasonal Variation in Semen Characteristics and Reaction Time of Tharpakar, Hariana and Taylor Bulls. Indian $J$. Dairy Sci. 19: 83-86.

Siratskii, I.Z. 1990. Inheritance of reproductive ability of bulls. Tsitol. Genet. 24: 28-34.

Smirnov, I.V. \& Kruglyak, A.P. 1980. Seasonal variation in semen production in Dices bulls. Anim. Breed. Abstr. 48: 68-71.

Steel, R.G.D. \& Torrie, J.H. 1980. Principles and Procedures of Statistics. A Biometrics Approach . McGraw-Hill, New York.
Tomar, N.S., Misra, B.S. \& Johari, C.B. 1966. Seasonal variations in reaction time and semen production and prediction of some semen attributes on initial motility of spermatozoa in Hariana and Murrah bulls. Indian J. Dairy Sci. 19: 87-93.

Tomar, S.S. \& Gupta, H.C.L 1984. Effect of season on sex desire and semen quality of Hariana bulls. Indian J. Anim. Health. 19: 37-40.

Vincent, C.K 1972. Effects of season and high environmental temperature on fertility in cattle: a review. J. Am. Vet. Med. Assoc. 161: 1333-1338.

Manuscript Received on 05.12.07, Accepted on 15.01.08 